\title{
A MIMO-technológia polgári és katonai alkalmazási lehetőségei
}

\section{The Possible Civilian and Military Applications of the MIMO Technology}

A MIMO²-t, azaz a több bemenettel és több kimenettel rendelkező rádiókommunikációs technológiát manapság egyre több területen alkalmazzák. Az újabb generációs mobilhálózatok - különös tekintettel a $4 \mathrm{G} \mathrm{LTE}^{3}$-re és az $5 \mathrm{G}$-re -, valamint még sok más RF-technológia (például WiMAX ${ }^{4}$, Wi-fi) élvezi a MIMO által szolgáltatott megnövekedett csatornakapacitás és a megbízhatóság előnyeit. Természetesen ezeket nemcsak a polgári életben lehet kihasználni, hanem a katonai felhasználások területén, például radar-, harcászati rádió- vagy pilóta nélküli légijármü-rendszerek $\left(U_{A S}^{5}\right)$ esetén is. A jelenleg is folyamatban lévő honvédelmi és haderőfejlesztési program jelentős anyagi forrásokat biztosít a Magyar Honvédség számára a technikai eszközrendszer modernizációjára, ugyanakkor a kommunikációs megoldások fejlesztéséröl mostanáig nem sokat lehetett megtudni. Véleményem szerint a program célkitüzéseivel összhangban olyan irányú fejlesztések is indokoltak lehetnek, amelyek a MIMO-technológia minél szélesebb körü jövőbeni katonai alkalmazására irányulnak.

Kulcsszavak: MIMO, 5G, müholdas kommunikáció, radar, UAV

The MIMO, the so-called multiple input and multiple output radio communication technology, is used in more and more fields. The last generation of mobile networks, especially the 4G LTE and 5G and many other RF technologies (WiMAX, Wi-Fi), benefit from the increased channel capacity and reliability provided by MIMO. Of course there are not only civilian but also military applications of MIMO, for instance radar, military radio or unmanned aerial vehicle systems. The ongoing Zrínyi 2026 Defence

\footnotetext{
Nemzeti Közszolgálati Egyetem Hadtudományi és Honvédtisztképző Kar, egyetemi hallgató, e-mail: viragh. krisztian97@gmail.com, ORCID: https://orcid.org/0000-0003-4184-9492

Multiple-Input, Multiple-Output - Több bemenet, több kimenet.

Long Term Evolution - Hosszú távú fejlődés.

Worldwide Interoperability for Microwave Access - Mikrohullámú hozzáférés az egységes interoperabilitásért.

Unmanned Aerial System - Pilóta nélküli légijármü-rendszerek.
} 
and Armed Forces Development Programme provides the Hungarian Defence Forces financial support for the modernisation of technical equipment. However, the development of communication systems is not intended in the Programme so far. I think that in accordance with the goals of the Programme, the development of MIMO technology may be necessary because of the wide range of its possible military applications in the future.

\section{Keywords: MIMO, 5G, SATCOM, Radar, UAV}

\section{Bevezetés}

Globalizált világunkban az elektronikus hírközlés az egyik legfontosabb szegmens a magánéletben, az üzleti (vállalati), illetve állami szférában egyaránt, hiszen az információcsere sebessége alapjaiban határozza meg az igénybe vett szolgáltatások minőségét az élet minden területén. A világ fejlett részei évtizedek óta rendelkeznek mobilhálózati és internetes lefedettséggel, ahol a kialakított infrastruktúra mindig a kor technikai színvonalának megfelelő szinten biztosítja a legkülönbözőbb szolgáltatásokat. Az előfizetők (végpontok) számának folyamatos és jelentős ütemü növekedése eredményeképpen a hálózatok újra és újra elérik technológiai korlátjaikat, azaz nem képesek az emberek növekvő igényeinek tovább megfelelni. A vezeték nélküli kommunikáció területén erre a problémára kínál egyféle megoldást a több bemenetü és több kimenetű MIMO-technológia, ami képes kiszolgálni a szélessávú adatátvitel igényeit, a korábbinál kiterjedtebb lefedettséget és magasabb megbízhatóságot kínálva a felhasználóknak. Ezért tartom szükségesnek a MIMO-alapú perspektivikus megoldások vizsgálatát, amelyeknek várhatóan kulcsfontosságú szerep jut majd többek között az 5G-hálózatok vagy különböző katonai alkalmazások fejlesztése során.

\section{A barlangrajzoktól a MIMO-ig}

A hírközlés története egészen az emberi beszéd megjelenése előtti időkre nyúlik viszsza, gondoljunk a barlangrajzokra, amelyeket az ősember egyfajta információközlési módszerként kívánt használni többi fajtársa felé (feltételezhetően nem a jövő embere számára kívánta megörökíteni a halászó, vadászó eljárásokat, vallási szokásokat). Az élet bizonyos területein azonban ez nem minősült hatékonynak egy-egy váratlan helyzetre való reagálás (ragadozó, táplálék megjelenése) esetében, ezért kénytelen volt áttérni egy alternatív közlési módszer használatára, amely a hangokhoz történő jelentéstársítást jelentette. Az évezredek során ezekből alakult ki a beszéd, a területi elszeparáltságnak köszönhetően pedig létrejöttek a különböző nyelvek. A civilizáció megjelenésével növekedett az igény az információ rögzítésére, ezért elkezdték a kimondott hangokat kőtáblákra, fába, majd papiruszra és papírra vetni, így kialakult az írás. Az írást az egymás közti (akár majdnem valós idejü) információközlésre is alkalmazták, ami a futár- és postahálózat kialakulásához vezetett. A könyvek kezdeti megjelenésével azok nem tudtak széles körben elterjedni, hiszen az emberek többsége analfabéta volt, illetve nem álltak rendelkezésre nagy számban könyvek, 
mivel a sokszorosításra egyedül a korábbi művek kézzel történő másolásával nyílt lehetöség, amely hosszadalmas folyamat volt. Ezzel kapcsolatosan áttörést jelentett a 15. században a könyvnyomtatás feltalálása, ami Johannes Gutenberg nevéhez köthető. Az első ténylegesen technikai eszközökkel megvalósított távközlési megoldásra egészen a 18. századig kellett várni, amikor 1787-ben Chudy József redőnyös optikai távíróját bemutatta Pozsonyban. Hozzá hasonlóan pár évvel később Claude Chappe sikeresen kiépített egy optikai távíró rendszert, amellyel 1794. augusztus 30-án sikerült jelentenie Párizsba Condé visszafoglalásának hírét. A következő fontos találmány Samuel Thomas von Sömmerring munkája volt, aki 1809-ben megalkotta az első elektromos távírót. Rendkívül fontos mérföldkő volt a hírközlés történetében, amikor Samuel Morse megalkotja a saját elektromos távíróját, amelyhez egy sajátos kódnyelvet (Morse-kód) is kidolgozott. E találmányait 1837-ben szabadalmaztatta. Eddig írott szöveget már sikeresen tudtak továbbítani viszonylag rövid idő alatt, azonban a hang valós idejü továbbítására még várni kellett egészen 1876-ig. Ekkor Alexander Graham Bell megalkotta az első távbeszélőt (az első telefon feltalálójának személye még a mai napig vitatott, ugyanis több, a hang továbbítására alkalmas eszközt találtak fel Bell előtt). Ez idő tájt építették meg az első telefonközpontot is, amely Puskás Tivadar nevéhez köthető. Guglielmo Marconi 1895-ben megalkotta a mobiltelefonok ősét, amely egy általa feltalált vezeték nélküli távíró volt. A távközlés fejlődési üteme, mint minden más technológiáé, rohamosan felgyorsult a 20. században a második és harmadik ipari forradalom következtében [1], [2].

Bell távbeszélőjével és Marconi a távírójával rakta le a távközlés további fejlődésének szilárd alapjait. Újabb technológiai vívmányok megjelenésével később lehetővé vált a vezeték nélküli hangtovábbítás is. Az első rádióadás, amely emberi hangot továbbított, Lee de Forest nevéhez füződik, aki 1910-ben a Metropolitan operaház egy előadását közvetítette. A hadsereg a rádiókban nagy lehetőségeket látott, így az első világháború idején már nagy számban alkalmazták azokat. A második világháborúig a rádiózás fejlődése főként katonai kereteken belül zajlott, majd azt követően egyre jobban átszivárgott a polgári életbe is [2]. 1945-ben megalkották a mobil rádiótelefont, amely a mobil telekommunikáció nulladik generációjának (OG) számított. 1973-ban Martin Cooper egy prototípus mobiltelefonnal végrehajtotta az első mobiltelefonhívást. A mai értelemben vett mobiltelefonok elődjeinek megjelenésére ugyanakkor csak az 1980-as években került sor. Az első vezeték nélküli, cellás rendszerek kiépítése ezzel párhuzamosan zajlott, amelyek jellegzetessége volt, hogy analóg jelek továbbítására voltak kifejlesztve. Ez volt az első generáció (1G). Az 1980-as évek végétöl a második generációs $(2 \mathrm{G})$ rendszerek már digitális jelek továbbítására voltak alkalmasak, amit a GSM ${ }^{6}$-rendszerek kiépülése tett lehetővé. Ezután ezeket a rendszereket folyamatosan fejlesztették, amely a GPRS ${ }^{7}$ - és az $\mathrm{EDGE}^{8}$-technológiák kialakulásához vezetett [3]. Ezt a 2G és a 3G közötti átmenetként, 2,5G-ként tartjuk számon. A 2000-es évek elején kezdték alkalmazni a 3G-t, amely az UMTS9-rendszerrel nem szorította ki teljesen elődjét, hiszen egymással párhuzamosan még ma is használják

Global System for Mobile Communications - Globális mobilkommunikációs rendszer.

General Packet Radio Service - Általános csomagkapcsolt rádiószolgáltatás.

Enhanced Data rates for GSM Evolution - Javított sebesség a GSM evolúciójáért.

Universal Mobile Telecommunications Systems - Egységes mobil telekommunikációs rendszer. 
mindkettőt. Ezt követően is megjelentek átmeneti rendszerek, mint a 3,5G a HSDPA ${ }^{10}$ és HSDUA ${ }^{11}$-val, a 3,75G a HSPA ${ }^{12}$-val, vagy a 3,9G az LTE nem végleges verziójával. 10 éven belül ugyanakkor már használatba álltak a következő, negyedik generációs (4G) mobil telekommunikációs rendszerek is az LTE végleges verziójával, ami teljesen IP-alapú, kis késleltetésü, nagyon gyors adatátvitelt tesz lehetővé [4]. Manapság zajlik a legújabb, 5G-s hálózatok fejlesztése is, amely minden eddiginél jobb képességekkel rendelkezik majd. Ebben kulcsfontosságú szerep jut a MIMO-technológiának is, amely habár csak nemrég került az érdeklődés fókuszpontjába, már sok évvel ezelőtt kigondolt technológia volt.

A MIMO története az 1970-es évekig nyúlik vissza. Igaz, ekkor főként az analóg távközlési rendszerek élték virágkorukat, de már ekkor foglalkoztatta a kutatókat a többcsatornás, digitális jelátvitel lehetősége [5]. Ekkor még nem célzottan a MIMOtechnológiát kutatták, azonban az ekkor megteremtett matematikai apparátus is hozzájárult annak további fejlődéséhez. Ez a tendencia egészen az 1990-es évek elejéig volt jellemző, amikor egy fontos mérföldkőként jellemezhető technológiát, a térosztásos többszörös csatornahozzáférési (SDMA) ${ }^{13}$ módot dolgozták ki. Ez szolgált ténylegesen a MIMO-technológia alapjául [6]. A MIMO-technológia müszaki alapjainak kigondolására azonban még 1993-ig várni kellett. Ekkor Arogyaswami Paulraj és Thomas Kailath egy sajátos metódust dolgoztak ki arra, hogy hogyan növelhetik a szélessávú vezeték nélküli kommunikációs rendszerek csatornakapacitását, és ezáltal hogyan szolgálhatnak ki tömegesen felhasználói igényeket [7]. Nem sokkal ezután, 1996-ban Gregory Raleigh az ortogonális frekvenciaosztásos multiplexelés (OFDM ${ }^{14}$ ) ötletét is megfogalmazta, amely szintén egyik fontos építőköve a MIMO-technológiának. Az első, kísérleti MIMO-rendszert még ebben az évben ő építette ki és tesztelte le néhány társával együtt [8]. 2003-ban az IEEE ${ }^{15}$ létrehozott egy feladatorientált csoportot, ahol a célkitűzés a felhasználók számára 100 Mbit/s adatátviteli sebesség biztosításának megvalósítása volt. Ezt az IEEE 802.11n szabvánnyal tervezték elérni, ami a MIMO-OFDM-en alapult. A csoportnak tagja volt többek között az Airgo Networks is. Nekik sikerült elsőként ezeknek a feltételeknek megfelelő MIMO-OFDM termékeket kifejleszteni 2004-ben. A MIMO-t ezek után a vezeték nélküli helyi hálózatokhoz $\left(\mathrm{LAN}^{16}\right)$, illetve a $3 \mathrm{G} / 4 \mathrm{G}$-s telefonrendszerekhez standardizálták, ugyanis segítségével ki tudták szolgálni a kiterjesztett sávszélességü, zavarmentes adatátviteli igényeket, amire ezeknek a rendszereknek szükségük volt. Az IEEE 802.11n szabvány 600 Mbit/s adatátviteli sebességre lett képes hála a MIMO-OFDM-nek [9]. A 802.16e szabványon alapuló WiMAX kezdetben 30-40 Mbit/s sebességet tudott elérni, majd a 2011-es frissítéssel már 1 Gbit/s-ot, szintén a MIMO-OFDM használatával [10]. Az LTE adatátviteli szabvány is MIMO-OFDM-n alapul, ami 300 Mbit/s letöltési és 75 Mbit/s feltöltési sebesség biztosítására alkalmas [11].

\footnotetext{
High Speed Downlink Packet Access - Nagysebességű csomagletöltési hozzáférés. High Speed Uplink Packet Access - Nagysebességű csomagfeltöltési hozzáférés. High Speed Packet Access - Nagysebességű csomagkapcsolt hozzáférés.

Space-Division Multiple Access - Térosztásos többszörös csatorna-hozzáférés.

Orthogonal Frequency-Division Multiplexing - Ortogonális frekvenciaosztásos multiplexelés.

Institute of Electrical and Electronics Engineers - Villamosmérnökök szervezete.

Local Area Network - Helyi hálózat.
} 


\section{A MIMO-technológia alapjai}

\section{Müködési alapelvek}

A MIMO egy több bemenettel és több kimenettel rendelkező korszerủ rádiókommunikációs technológia, amelynek gyakorlati megvalósításához többféle technikai megoldást lehet alkalmazni:

- térbeli diverziti;

- ortogonális frekvenciaosztásos multiplexelés (OFDM) és többszörös hozzáférés $\left(\mathrm{OFDMA}^{17}\right)$;

- térbeli multiplexelés;

- nyalábformálás.

Térbeli diverziti

A térbeli diverziti bemutatása előtt szükséges egy másik jelenség, a fading ismertetése. Ez a rádióhullámok interferenciája miatt fellépő, jelszintingadozást okozó jelenség, amely hatással van a jel/zaj viszonyra, valamint digitális jelek esetén a bit/hiba arányra is. Az általa okozott hatások csökkentésének érdekében alkalmazzák a diverziti különböző formáit. A diverziti lényege, hogy az azonos modulációjú jelet valamilyen módon (időben, frekvenciában, térben) fel kell osztani és több átviteli útvonalon keresztül továbbítani a vevő felé. A jelet a különböző átviteli útvonalakon más-más hatás éri, így például ha az első jelnek az első fele értelmezhetetlen, akkor a második jelből még képes a vevő dekódolni a hiányzó jel többi részét. Ennek eredménye, hogy javul a jel/ zaj viszony és a bit/hiba arány. A diverzitinek háromféle alaptípusa van [12]:

- időosztásos: ebben az esetben különböző időpontokban továbbítják a jeleket, ehhez használhatnak például időszeleteket, frekvenciakódolást;

- frekvenciaosztásos: ebben az esetben különböző frekvencián továbbítják a jeleket. Ehhez használhatnak különböző csatornákat, illetve olyan eljárásokat, mint az OFDM;

- térbeli: a fizikai térnek különböző pontjain helyezik el az antennákat, és az így kialakuló rádiócsatornákat különböző tulajdonságok fogják jellemezni. Két módját különítjük el:

- adó-diverziti: az adó oldalon van több antenna (1. ábra),

- vevő-diverziti: a vevő oldalon van több antenna (2. ábra).

17 Orthogonal Frequency-Division Multiple Access - Ortogonális frekvenciaosztásos többszörös hozzáférés. 


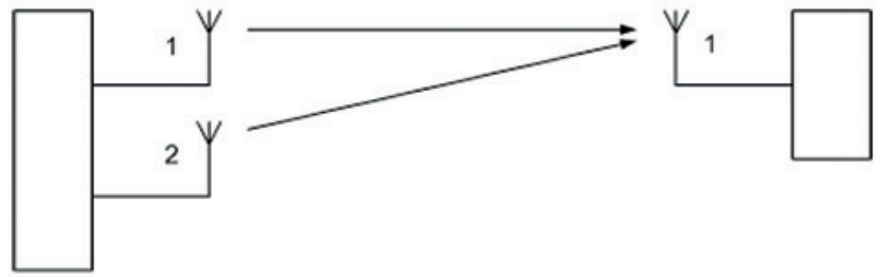

1. ábra

Adó-diverziti [13]

Az 1. ábrán látható műszaki megoldás, amellett, hogy bemutatja az adó-diverzitit, egy klasszikus példája a több bemenetű és egy kimenetü (MISO) ${ }^{18}$ távközlési rendszereknek.

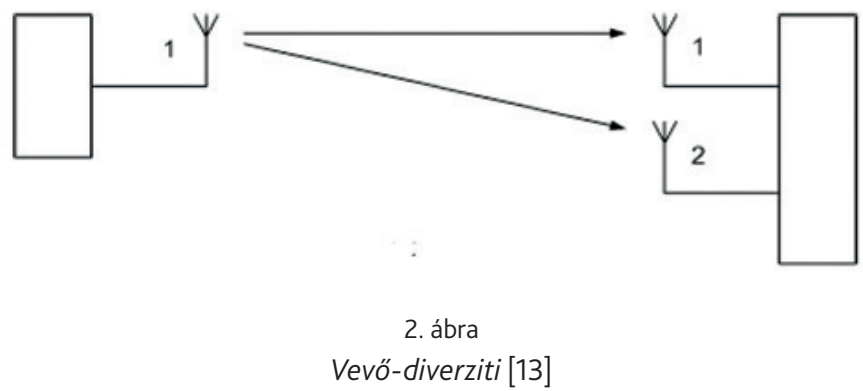

A 2. ábrán látható műszaki megoldás pedig az egy bemenetű és több kimenetű $(\mathrm{SIMO})^{19}$ távközlési rendszereknek egy jellegzetes példája.

\section{OFDM/OFDMA}

Az OFDM a frekvenciaosztásos diverziti egy módja. A vezetékes és vezeték nélküli mobil távközlésben egyaránt alkalmazzák. Alapgondolata az, hogy az adatátviteli csatornát sok, kisebb sávszélességű frekvenciasávra osztják fel, ahol az információt modulált alvivők továbbítják. Ezek a frekvenciasávok olyan sürün helyezkednek el, hogy köztük átlapolódás jön létre, amely alapesetben interferenciát okozna, azonban a frekvenciasávok alvivői ortogonálisak egymásra. Ez azt jelenti, hogy ahol az egyes alvivők maximumértéket vesznek fel, ott a többi alvivő értéke nulla, így nem jön létre interferencia (3. ábra) [14], [15].

\footnotetext{
Multiple-Input, Single-Output - Több bemenet, egy kimenet.

19 Single-Input, Multiple-Output - Egy bemenet, több kimenet.
} 


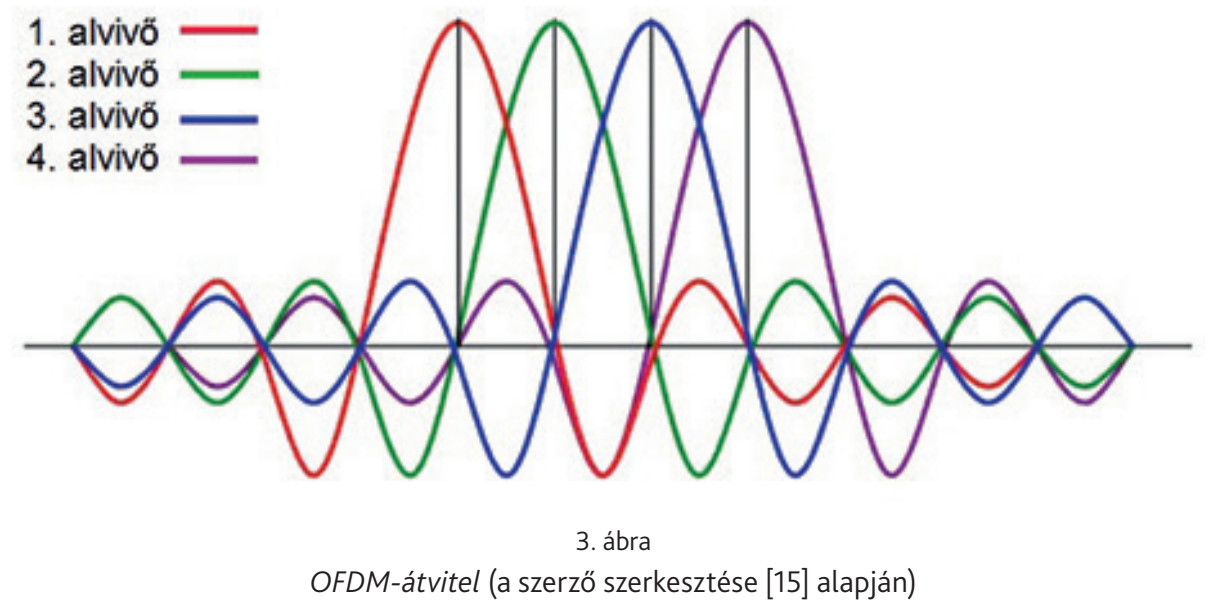

Térbeli multiplexelés

A térbeli diverziti mellett az úgynevezett térbeli multiplexelési eljárást is alkalmazzák. A térbeli multiplexelés lényege több adó- és vevőantenna, valamint több adatfolyam használata. A vevőantennák jelében más-más súlytényezővel szerepelnek az egyes adóantennák jelei. Az adás előtt megfelelő előkódolást és a vételkor megfelelő jelfeldolgozást alkalmazva így több független adatfolyam is átvihető a csatornán [16].

Nyalábformálás

A nyalábformálás szintén egy MIMO-technikának tekinthető, amely az antennarendszer sugárzási iránykarakterisztikájának létrehozására szolgáló módszer. Alkalmazható minden antennarendszerben, így a MIMO-rendszerekben is. Többféle módja van, amelyből kettőt elterjedten alkalmaznak [13]:

- kapcsolt nyalábformálás, véges számú sugárzási mintát biztosít;

- adaptív nyalábformálás [17], [18], végtelen számú sugárzási mintát biztosít, mindig a felhasználóhoz igazodva (komplexebb algoritmusokkal beazonosítja és követi a felhasználó jelét).

\section{Müszaki megoldások}

A MIMO-technológiának többféle müszaki megoldása létezik, amelyeket érdemes rendszerezni az átláthatóság érdekében. Legkézenfekvőbb az adó és vevő oldalon lévő 
antennák száma szerint csoportosítani, ami alapján megkülönböztethetjük az alábbi konstrukciókat [13] [19]:

- az egy be- és egy kimenet (SISO), ${ }^{20}$

- az egy be- és több kimenet (SIMO),

- a több be- és egy kimenet (MISO),

- a több be- és több kimenet (MIMO).
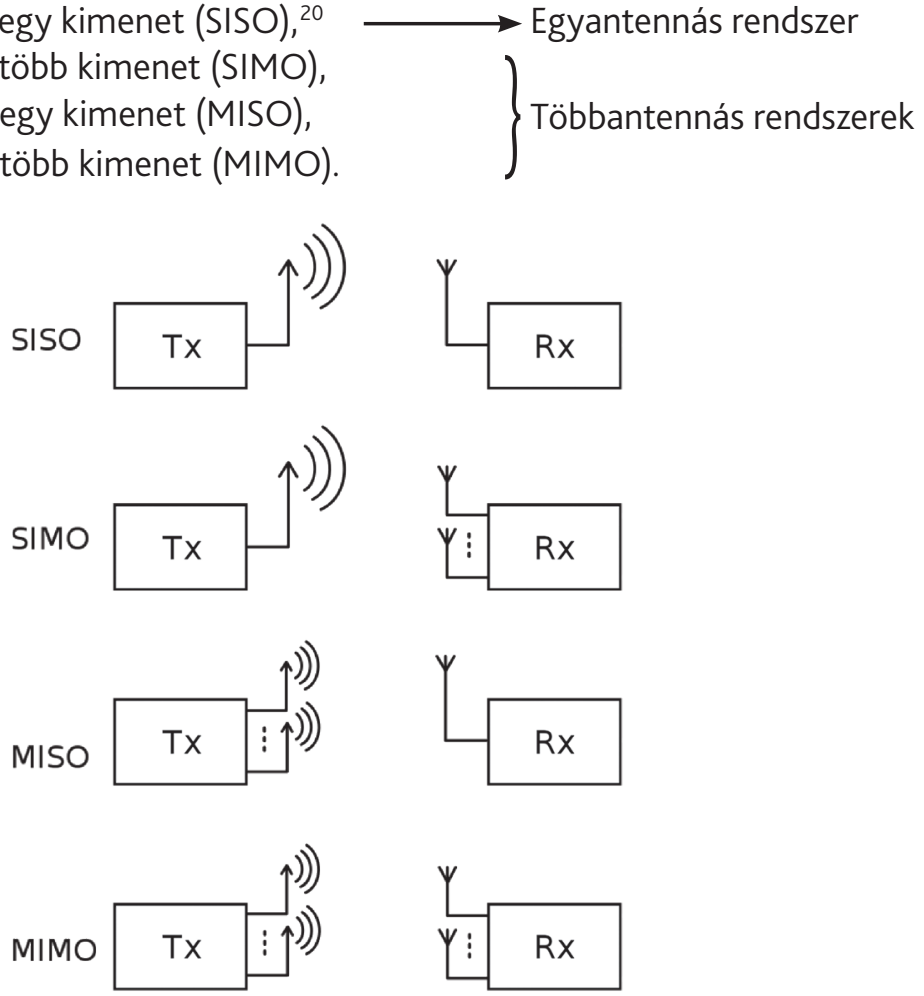

4. ábra

Az egyantennás rendszert nevezhetjük a hagyományos módszernek. Ez esetben mind az adó, mind a vevő oldalon az antennák száma egy-egy.

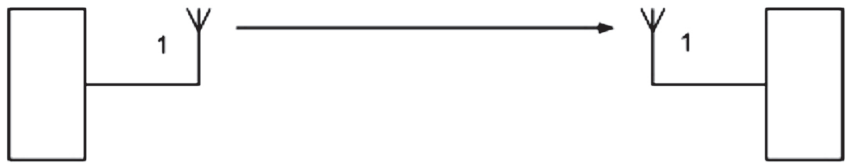

5. ábra

Egyantennás átvitel [13]

A Shannon-Hartley-tétel szerint az ilyen SISO-csatorna kapacitása (C) függ a sávszélességtöl (B) és a jel/zaj viszonytól $(S / N)$ :

20 Single-input, Single-output - Egy bemenet, egy kimenet. 


$$
\mathrm{C}=\mathrm{B} * \log _{2}\left(1+\frac{\mathrm{S}}{\mathrm{N}}\right)
$$

Többantennás átvitelnél az adó és a vevő oldalon lévő antennák száma m és n. Mivel az antennák ugyanazt a csatornamátrixot $(H)$ használják, így a vevőantennák nemcsak a saját, hanem más vevőantennáknak szánt jeleket is vesznek. Matematikailag a kapcsolatot kifejezve: y vektort (kimenet) megkapjuk, ha az x vektort (bemenet) a H csatornamátrixszal szorozzuk:

$$
y=x * H
$$

m számú adóantenna

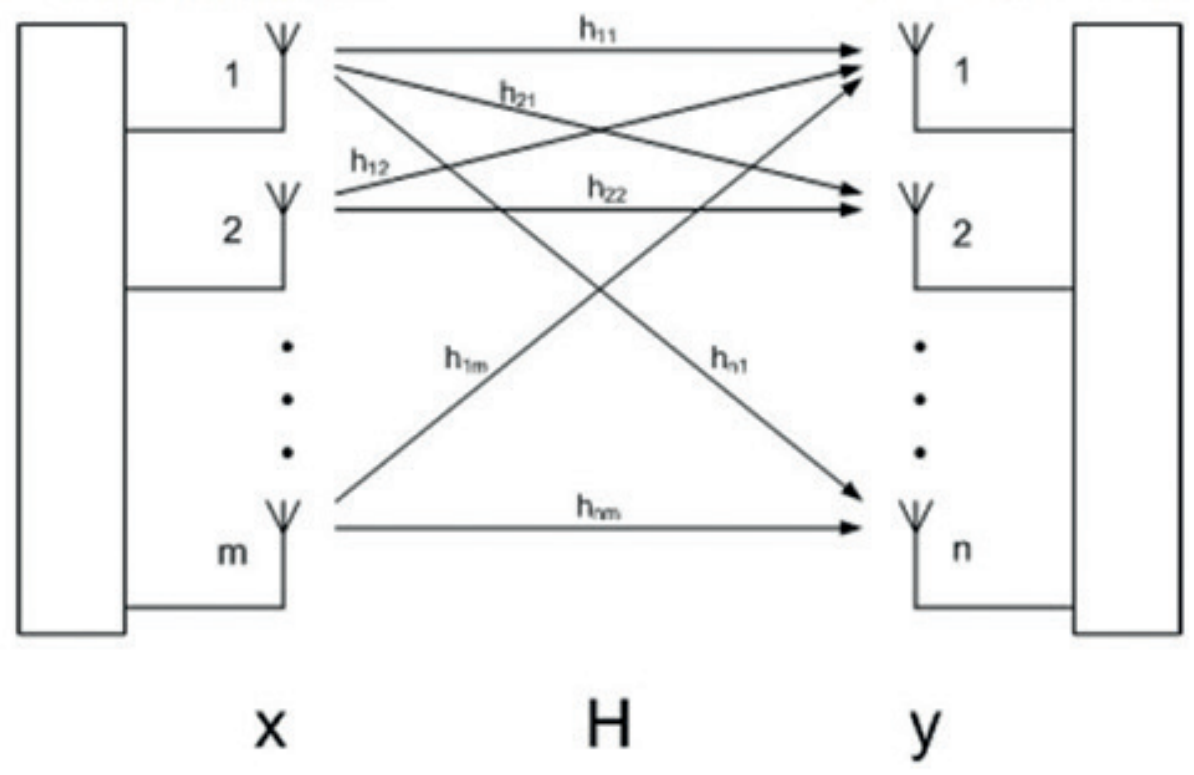

6. ábra

A csatornamátrixot elemezve megállapítható, hogy az első antennapár közötti kapcsolat leírására a $h_{11}$ vektor szolgál, a második antennapár közötti közvetlen kapcsolat leírását a $h_{22}$ vektor adja meg és így tovább. A korábbi gondolatmenet szerint azonban az első antennapár vevőantennájára nemcsak a vele párban lévő adóantenna, hanem a második antennapár adója $\left(h_{12}\right)$, a harmadik antennapár adója $\left(h_{13}\right)$ és az m-edik antennapár adója $\left(\mathrm{h}_{1 \mathrm{~m}}\right)$ is hat [21]. Ez az összefüggés a MIMO típusú átvitel sajátossága. Matematikailag a következőképpen írható le a csatornamátrix: 


$$
H=\left[\begin{array}{cccc}
h_{11} & h_{12} & h . . & h_{1 m} \\
h_{12} & h_{22} & h . . & h_{2 m} \\
h . . & h . . & h . . & h_{. m} \\
h_{n m} & h_{n 2} & h_{n .} & h_{n m}
\end{array}\right]
$$

Mivel a továbbítani kívánt adatokat független adatfolyamokra osztjuk szét, így a korábban SISO-csatornára felírt matematikai összefüggés módosul. Bevezetésre kerül az $\mathrm{E}_{\mathrm{n}}$ egységmátrix, a $\mathrm{H}$ csatornamátrix és annak $\mathrm{H}^{\prime}$ transzponált konjugált mátrixa. Alkalmazva a Shannon-Hartley-tételt a MIMO-átvitelre az alábbi összefüggést kapjuk:

$$
\mathrm{C}=\mathrm{B} * \log _{2}\left(\operatorname{det}\left(E_{n}+\frac{\mathrm{s}}{\mathrm{N}} * H * H^{\prime}\right)\right)
$$

Egy konkrét példán keresztül szemléltetve megérthetővé válik a korábban leírtak jelentősége:

1. eset:

Induljunk ki egy hagyományos SISO kommunikációs csatornából, amely $1 \mathrm{MHz}$-es sávszélességen (B) üzemel, $24 \mathrm{~dB}$-es jel/zaj viszonnyal $\left(\mathrm{S} / \mathrm{N}_{\mathrm{dB}}\right)$. A Shannon-Hartleytételt alkalmazva kiszámoljuk annak csatornakapacitását:

$$
\begin{gathered}
\frac{\mathrm{S}}{\mathrm{N}}_{\mathrm{dB}}=10 * \lg \frac{\mathrm{s}}{\mathrm{N}} \\
24=10 * \lg ^{\frac{\mathrm{S}}{\mathrm{N}}} \\
2.4=\lg \frac{\mathrm{s}}{\mathrm{N}} \\
\frac{\mathrm{S}}{\mathrm{N}}=10^{2.4}=251 \\
\mathrm{C}=10^{6} * \log _{2}^{(1+251)} \\
\mathrm{C}=10^{6} * \frac{\lg ^{252}}{\lg ^{2}} \\
\mathrm{C}=10^{6} * 7.977=8 \mathrm{Mbps} \\
\mathrm{C}=8 \mathrm{Mbps}
\end{gathered}
$$


2. eset:

Most vizsgáljuk meg, hogyan alakul a csatornakapacitás, hogyha ugyanezen értékekkel egy 2 × 2-es MIMO-rendszert üzemeltetünk.

$$
\begin{gathered}
\left(\mathrm{B}=1 \mathrm{MHz}, \mathrm{S} / \mathrm{N}_{\mathrm{dB}}=24 \mathrm{~dB}, \mathrm{E}_{2 \mathrm{X} 2}=\mathrm{H}=\mathrm{H}^{\prime}=\left[\begin{array}{ll}
1 & 0 \\
0 & 1
\end{array}\right]\right) \\
\mathrm{C}=10^{6} * \log _{2}\left(\operatorname{det}\left(\left[\begin{array}{ll}
1 & 0 \\
0 & 1
\end{array}\right]+251\left[\begin{array}{ll}
1 & 0 \\
0 & 1
\end{array}\right] \times\left[\begin{array}{ll}
1 & 0 \\
0 & 1
\end{array}\right]\right)\right. \\
\mathrm{C}=10^{6} * \log _{2}\left(\operatorname{det}\left(\left[\begin{array}{ll}
1 & 0 \\
0 & 1
\end{array}\right]+\left[\begin{array}{cc}
251 & 0 \\
0 & 251
\end{array}\right]\right)\right. \\
\mathrm{C}=10^{6} * \log _{2}\left(\operatorname{det}\left(\left[\begin{array}{cc}
252 & 0 \\
0 & 252
\end{array}\right]\right)\right. \\
\mathrm{C}=10^{6} * \log _{2}\left(\operatorname{det}\left(\left[\begin{array}{cc}
252 & 0 \\
0 & 252
\end{array}\right]\right)\right. \\
\mathrm{C}=10^{6} * \log _{2}^{(252 * 252-0)} \\
\mathrm{C}=10^{6} * \log _{2}^{(63504)} \\
\mathrm{C}=10^{6} * \frac{\lg ^{63504}}{\lg ^{2}} \\
\mathrm{C}=10^{6} * 15.955 \\
\mathrm{C}=16 \mathrm{Mbps}^{(255}
\end{gathered}
$$

Látható, hogy a csatornakapacitás megkétszereződött. Ezenfelül azt is ki lehet jelenteni, hogy ideális körülmények között minél több antennát alkalmazunk, annál megbízhatóbb a folyamatos adatáramlás, és ezáltal javul a rádióösszeköttetés minősége. A fizikai és a rádiófrekvenciás környezet változatossága, valamint a mobilkommunikáció területén jelentkező technológiai korlátok miatt (például mobiltelefonok esetében az eszközök kis mérete) a MIMO-eljárások nem minden esetben realizálhatók optimálisan [19].

A MIMO-átvitelen belül kétféle típust különíthetünk el [20]:

- az egyfelhasználós (SU-MIMO) $)^{21}$

- és a többfelhasználós (MU-MIMO) 22 átvitelt.

21 Single-user MIMO - Egyfelhasználós MIMO.

22 Multi-user MIMO - Többfelhasználós MIMO. 
Előbbi esetben az adatfolyamok egy időben egy eszközbe áramlanak több antennán keresztül (7. ábra). A SU-MIMO tökéletesen alkalmazható akkor, hogyha egy eszköznek robusztusabb hírközlést kell biztosítani nagy adatsebességgel. A legföbb probléma ezzel a típusú rendszerrel, hogy adott időben a teljes sávszélességet lefoglalja, így több felhasználót csak időosztásos módon tud kiszolgálni [22], éppen ezért csak speciális területeken alkalmazzák.

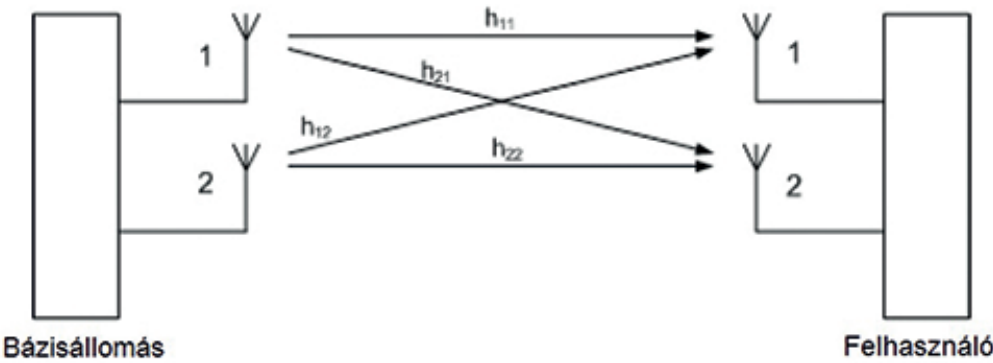

7. ábra

2 ×2-es SU-MIMO-átvitel (a szerző szerkesztése [13] alapján)

Utóbbi esetben az adatfolyamok egy időben több eszközbe áramlanak egy vagy akár több antennán keresztül (8. ábra). A SU-MIMO-val ellentétben itt a sávszélesség akár dinamikusan is felosztható a felhasználók között, így az igények tömeges kiszolgálása is lehetséges [22].

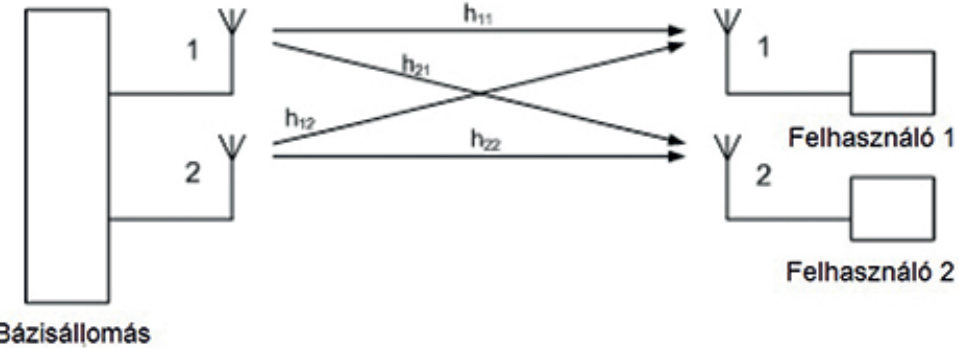

8. ábra

2×2-es MU-MIMO-átvitel (a szerző szerkesztése [13] alapján)

Mindenféleképpen megemlítendő a masszív MIMO koncepciója. Az LTE maximum nyolc $(8 \times 8)$, szektorokba rendezett antennát alkalmaz a felhasználók kiszolgálására. A masszív MIMO akár 64-nél is több antennát foglal magában, rajtuk több száz antennaelemmel. Ez a korábbinál még nagyobb számú felhasználó egyidejü kiszolgálását biztosítja. Ezenfelül előfeldolgozással a megcélzott mobilkészülék felé koncentrálja a kisugárzott jelet, így csökkenti a kisugárzott teljesítményt is [23], [24]. 


\section{Használatának elönyei és hátrányai}

A MIMO-rendszerek jellemzőit érdemes pontokba gyüjteni, hogy áttekinthetővé váljanak azok előnyei és hátrányai egy SISO kommunikációs rendszerhez képest. Előnyei a müködési alapelvek sajátosságaiból eredően [25]:

- csökken a fading hatása;

- javul a jel/zaj viszony;

- javul a bit/hiba arány;

- nő a csatornakapacitás;

- nő az adatátviteli sebesség;

- nő a lefedettség mértéke.

Hátrányai [25]:

- komplex a rendszer hardver- és szoftverszintű kiépítése;

- az eszközöket több antennával felszerelni költségesebb, növeli az eszköz tömegét, méretét;

- a fejlettebb hardver- és szoftvertechnológiai igények miatt nagy az erőforrásigénye;

- nagy a rendszer energiaigénye, hiszen komplex jelfeldolgozási algoritmusokat és digitális jelfeldolgozó processzorokat (DSP23) kell alkalmazni.

\section{Polgári alkalmazási lehetőségek}

Ebben a fejezetben a MIMO két polgári alkalmazási módját ismertetem, amelyek a jövőben nagy jelentőséggel bírhatnak a civil szféra minden területén. Ez a két felhasználási lehetőség az:

- ötödik generációs mobil telekommunikációs rendszerek (5G);

- és a múholdas kommunikáció (SATCOM²4).

\section{G-rendszerek}

Az ötödik generációs mobilkommunikációs hálózatok öt kulcsfontosságú alapvetésre épülnek. Ezek a [26]:

- milliméteres hullámtartomány;

- kis cellás hálózatok;

- masszív MIMO;

- nyalábformálás;

- kétirányú kommunikáció (Full duplex).

23 Digital Signal Processor - Digitális jelfeldolgozó processzor.

24 Satellite Communications - Müholdas kommunikáció. 
A polgári életben a legtöbbször alkalmazott eszközök a 3 kHz és $6 \mathrm{GHz}$ közötti frekvenciatartományban üzemelnek, azonban mára olyan sok eszköz müködik ebben a frekvenciasávban, hogy elértük annak korlátait, így indokolt a frekvenciasáv kiszélesítése a milliméteres hullámtartományba, ami $300 \mathrm{GHz}$-ig terjed. Ezen frekvenciájú jelek azonban nem rendelkeznek jó terjedési tulajdonságokkal, nem tudnak áthatolni a terjedés útjában álló akadályokon és könnyen elnyelödnek például a növényzeten való szóródás vagy éppen a csapadékokban történő elnyelődés miatt. Ennek kiküszöbölése érdekében alkalmazzák a kis cellás hálózatokat, amelyek olyan mobilis, miniatürizált bázisállomásokból állnak, amelyek müködtetéséhez minimális energiafelhasználás szükséges. A bázisállomásokat egy erősen átszegdelt terepen néhány tíz méterenként kell elhelyezni a megfelelő kommunikációs csatorna biztosítása érdekében, így enyhíthető a milliméteres hullámtartomány rossz terjedési tulajdonságából eredő nagy csillapítás [27].

A nagyszámú felhasználó egyidejü kiszolgálását masszív MIMO-val lehet realizálni a már korábban kifejtett elven. Az egyidőben forgalmazó nagyszámú felhasználó interferenciát okoz, ezt elkerülendő használnak különböző nyalábformálási technikákat. Különböző komplex algoritmusok segítségével [28] kiválasztják az adathordozó jelek számára az optimális útvonalat, és a megfelelő időben továbbítják azt. A nyalábformálás tovább növelheti a jelerősséget, ugyanis tünyalábok használatával messzebbre tudjuk továbbítani a jelet, hiszen ugyanakkora energiának kisebb területre kell koncentrálódnia, mintha minden irányba sugároznánk, így a milliméteres hullámtartománynak a rossz terjedési tulajdonsága még tovább enyhíthető [29].

A Full-duplex (kétirányú kommunikáció) lényege, hogy az eszközök egyszerre tudnak adni és venni ugyanabban az időben, ugyanazon a frekvencián. Annak az 5G-be való integrálásával a vezeték nélküli hálózatok kapacitását meg lehet duplázni. Ez egy olyan áramkört igényel, amely szét tudja választani a kimenő és a beérkező jeleket, így azok nem keverednek, miközben az antenna üzemel. Ezt szilíciumtranzisztorokkal érik el, amelyek nagysebességű kapcsolóként viselkednek a rendszerben [26].

A fentieket figyelembe véve érdemes összegezni az 5G-technológia által biztosított elönyöket [3]:

- felhasználók egyidejü tömeges kiszolgálása;

- gigabites sávszélességű adatátviteli sebesség;

- magas letöltési és feltöltési sebesség;

- megbízható kommunikációs csatorna.

Ezekre alapozva kijelenthető, hogy az 5G akár ezerszer nagyobb adatforgalmat lesz képes majd lebonyolítani ugyanannyi idő alatt, mint a 4G LTE. Éppen emiatt egy HDfilm letöltése néhány másodperc alatt megtörténhet. Olyan technológiák mindennapi életbe való szervesebb integrálásához járul majd hozzá, mint a virtuális valóság $\left(V R^{25}\right)$, önvezető jármüvek [30], a dolgok internete $\left({ }^{\circ} \mathrm{T}^{26}\right)$ vagy az egyre népszerübbé váló mesterséges intelligencia $\left(\mathrm{Al}^{27}\right)$.

\footnotetext{
Virtual Reality - Virtuális valóság.

Internet of Things - Dolgok internete.

Artificial Intelligence - Mesterséges intelligencia.
} 


\section{Müholdas rendszerek}

A mủholdas kommunikáció már 60 éve igen jelentős szerepet tölt be a kommunikációs hálózatok kiterjesztésében a világon. Ehhez különböző magasságokban lévő müholdakat alkalmaznak. Elkülönítjük [31]:

- az alacsony röppályájú müholdakat (LEO²8);

- a geostacionárius múholdakat (GEO $\left.{ }^{29}\right)$;

- a közepes röppályájú müholdakat $\left(\mathrm{MEO}^{30}\right)$;

- és a nagy excentricitású, elnyújtott ellipszis röppályájú müholdakat (HEO¹).

A távközlésben általában LEO és GEO müholdakat alkalmaznak. Ezek az alábbi frekvenciasávokat használják [31]:

- ultramagas frekvenciájú hullámok tartománya $\left(\mathrm{UHF}^{32}\right)$ : a $300 \mathrm{MHz}-3 \mathrm{GHz}$ közötti hullámtartományban, föként hang- és adattovábbításra alkalmazzák. A katonai müholdkommunikációban (MILSATCOM ${ }^{33}$ ) előszeretettel használják kisméretü antennái, azok mobilitása és megbízhatósága miatt. A hagyományos MILSATCOM rendszerek e tartományban a 292-317 MHz közötti uplink és 244-270 MHz közötti downlink frekvenciasávokban müködnek.

- L-sáv: a 1-2 GHz közötti hullámtartományban alkalmazzák müholdas mobil kommunikációs rendszereknél, például az Iridiumnál.

- S-sáv: a 2-4 GHz közötti hullámtartományban alkalmazzák, föként légtérellenörző rendszereknél, időjárás-elörejelző radaroknál vagy éppen kommunikációs célú müholdaknál.

- C-sáv: a 4-8 GHz közötti hullámtartományban alkalmazzák a müholdas televíziós műsorszóró hálózatoknál.

- X-sáv: a 8-12 GHz közötti hullámtartományban alkalmazzák. MILSATCOM rendszerek a 7,9-8,4 GHz közötti uplink és 7,25-7,75 GHz közötti downlink frekvenciasávokban üzemelnek.

- Ku-sáv: a 12-18 GHz közötti hullámtartományban alkalmazzák a kereskedelmi televíziós és egyéni müholdas müsorszórásnál.

- Ka-sáv: a 27-40 GHz közötti hullámtartományban alkalmazzák. MILSATCOM rendszerek a 30-31 GHz közötti uplink és 20,2-21,2 GHz közöti downlink frekvenciasávokban üzemelnek.

Müholdas MIMO-kommunikáció megvalósításához tipikusan az UHF hullámtartományt, az S, X, Ku és Ka sávokat használják. E frekvenciasávokban müködő kommunikációs csatornákra az egyenes vonalú (LOS) ${ }^{34}$ hullámterjedés jellemző, amelynek hátrányait az antennák földrajzi szeparációjával tudjuk orvosolni. Mivel állandó, stabil

\footnotetext{
Low-Earth Orbit - Alacsony röppályájú mühold.

Geostationary Earth Orbit - Geostacionárius mühold.

Medium-Earth Orbit - Közepes röppályájú mühold.

Highly Elliptical Orbit - Ellipszis röppályájú mühold.

Ultra High Frequency - Ultramagas frekvencia.

Military Satellite Communications - Katonai müholdas kommunikáció.

Line of Sight - Látótávolság.
} 
kommunikációs kapcsolatra van szükség, így a geostacionárius müholdak alkalmazása indokolt MIMO-kapcsolat esetében, hiszen a Földdel szinkronban keringve folyamatosan ugyanabba a terjedési síkba néznek, így kiküszöbölhető a doppler-jelenség, ami felléphetne például egy LEO-pályás mühold esetében.

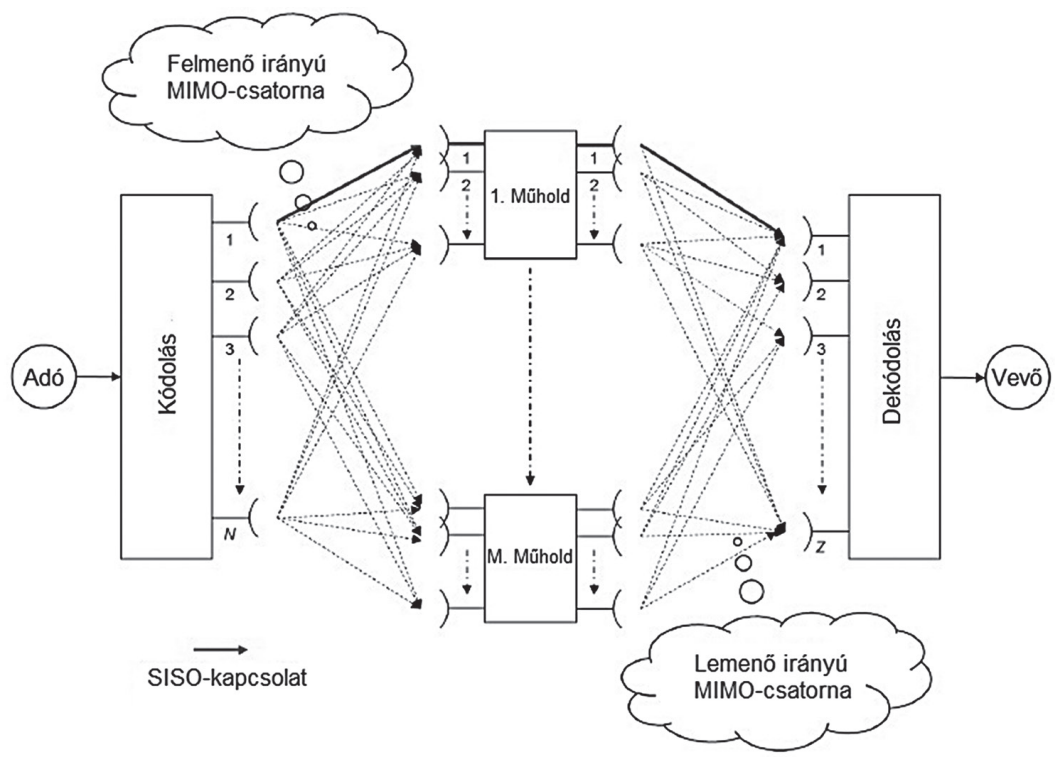

9. ábra

Müholdas MIMO-kommunikációs modell [31]

A müholdas MIMO-rendszerek működési elvének (9. ábra) értelmezése egyszerü, hiszen az eddigi több be- és több kimenetű kommunikációs modell bővült a müholdakkal mint közvetítő eszközökkel. Az adó fél által küldeni kívánt információ kódolása után az N számú adóoldali MIMO-antenna továbbítja a kódolt jeleket az M számú müholdaknak, amelyeket a Z számú vevőoldali MIMO-antennák fogadnak, majd erősítés és transzponálás után visszasugároznak a földre a címzett (vevő) felé.

\section{Katonai alkalmazási lehetőségek}

Ebben a fejezetben a MIMO két katonai alkalmazási módját ismertetem, amelyek a jövőben nagy jelentőséggel bírhatnak a katonai-biztonsági területen. Ez a két felhasználási lehetőség:

- a radarrendszerek;

- a pilóta nélküli légi jármüvek (UAV) ${ }^{35}$.

35 Unmanned Aerial Vehicle - Pilóta nélküli légi járművek. 


\section{Radarrendszerek}

Azokat a fejlett, fázisvezérelt radarrendszereket, amelyek apertúráját digitális vevőkkel és hullámforma-generátorokkal ellátva alakítják ki, MIMO-radaroknak nevezzük. Egy hagyományos fázisvezérelt radarrendszerben további antennák és a hozzájuk köthető egyéb hardver telepítése szükséges a térbeli felbontás javításához. Ez a MIMO-radarrendszerekben is elérhető ortogonális jelek sugárzásával, további antennák és hardverek telepítése nélkül. Például egy $4 \times 4$-es MIMO-antennakonstelláció esetén 16 féle jel választható szét a vevőben a kisugárzott jelek ortogonalitása miatt. Tehát egy 8 antennából álló MIMO-rendszerrel megalkottunk egy 16 elemes virtuális antennarácsot digitális vevőoldali jelfeldolgozással. Ezzel a megoldással az egyszerü fázisvezérelt radarrendszerekéhez képest jobb térbeli felbontást kapunk [32]. Ezenfelül ellenállóbbak a zavarokkal szemben is, valamint a jel/zaj viszony javulása miatt a felderítési képesség is növekszik [33]. A MIMO-radaroknak két fajtáját különítjük el:

- mono-statikus MIMO-radarok;

- bi-statikus MIMO-radarok.

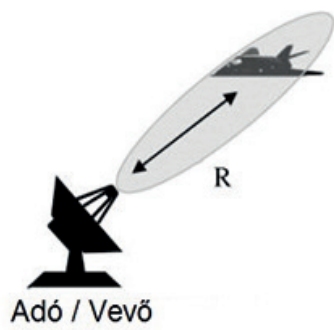

a)

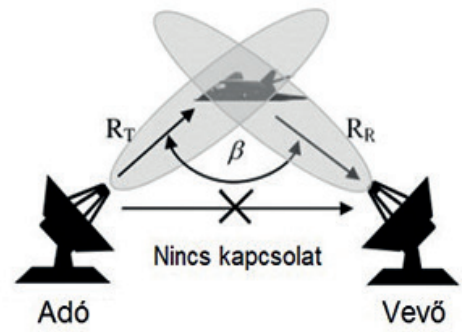

b)

10. ábra

Mono-statikus (a) és bi-statikus (b) radarrendszerek [34]

Mono-statikus MIMO-radarok

Ebben az esetben az összes adó- és vevőantenna nagyjából ugyanarra a helyre van telepítve. Az adóantennák elég közel vannak egymáshoz ahhoz, hogy a célpont radarkeresztmetszete minden antennaelemhez viszonyítva ugyanolyan legyen. Ez a rendszer hasonló a fázisvezérelt antennák egy olyan fajtájához, ahol minden adóantennának saját adóvevő modulja és A/D (analóg/digitális) konvertere van. A különbség a fázisvezérelt és a MIMO-antennarendszer között az, hogy míg a fázisvezérelt antennák esetében minden adóantenna csak a továbbítandó jel egy másolatát sugározza, amit egy központi hullámforma-generátor hoz létre, addig a MIMO-antennák esetében minden adóantennának saját hullámforma-generátora van, amelyek egyedi hullámformákat hoznak létre [32]. 


\section{Bi-statikus MIMO-radarok}

Ebben az esetben az adó- és a vevőantennák egymástól elkülönítve vannak elhelyezkedve. Pontosan emiatt mindegyik antennapár különböző szögben néz a célpont felé, ami más-más radarkeresztmetszetet eredményez, ezáltal az összes jel összehangolása összetettebb jelfeldolgozást igényel [32].

\section{Pilóta nélküli légi jármüvek}

Manapság rohamtempóban fejlődnek a személyzetet a fedélzetén nem hordozó jármúvek [35], [36]. Ezeknek egy csoportja a pilóta nélküli légi jármúvek, vagy másnéven az operátorok által távolról vezérelt repülőeszközök (RPA) ${ }^{36}$. A különböző szintű katonai feladatok kivitelezéséhez rendkívül megbízható kommunikációs csatorna szükséges a légi járművek és az operátorok között. Ezt képes biztosítani a több bemenettel és több kimenettel rendelkezö technológia [37].

Az UAV-k feladatrendszere mára rendkívül kiterjedt és képesek ellátni akár olyan feladatokat is, mint [38]:

- célpontok likvidálása;

- harci és felderítési információk megszerzése;

- célmegjelölés;

- hírszerzés;

- megfigyelés;

- harctéri kutatás és mentés;

- elektronikai és információs hadviselési feladatok.

Ilyen típusú feladatok kivitelezésénél a kommunikációs csatornán érzékeny információk mennek keresztül, így mindent meg kell tenni annak zavarása, lehallgatása elkerülésének érdekében. Kijelenthető, hogy kritikus tényezővé vált a katonai célra használt UAV-k kommunikációs csatornájának esetében a megbízhatóság és zavarellenálló-képesség. Csaknem ugyanilyen fontos tényező az, hogy nagy mennyiségű adatokat lehessen továbbítani a csatornán keresztül, hiszen több feladat magában foglalja nagyfelbontású fényképek, valós időben közvetített videók továbbítását, megjelenítését. Eddig a MIMO-technológia alkalmazása nem volt jellemző a légi járművek esetében, hiszen kimondottan átszegdelt terepen lehet hatékonyan alkalmazni ezeket a többutas hullámterjedés kihasználása miatt [39]. Vannak azonban olyan távolságok, ahol a többantennás rendszerrel hatékonyabban lehet kommunikációs csatornát létrehozni a földi irányítóállomás és az RPA között, mint az egyantennás rendszerrel [40]. Habár a MIMO-technológia alapvetően meg tud felelni az UAV-k feladatkörei által támasztott igényeknek, a gyakorlati alkalmazásokat több probléma is nehezíti [37]:

- a légtérben a többutas hullámterjedés során fellépő kedvező jelenségek kihasználása sok esetben körülményesebb, mint a földfelszíni összeköttetések esetén, hiszen vagy megfelelő reflektálóképességgel rendelkező bevonattal (például alumínium)

36 Remotely Piloted Aircrafts - Távolról Vezérelt Repülőeszközök. 
rendelkező UAV-t kell alkalmazni, és/vagy a földi vevőantennák környezetének jellegzetességeit kell hatékonyabban kihasználni;

- megfelelö reflektáló felület nélkül a LOS-hullámterjedés túlságosan lekorlátozza a lehetőségeket, hiszen az UAV-ken található antennák egyes elemei teljesen kívül eshetnek a csatornán;

- az UAV-k nagyfokú manőverezőképessége tovább nehezítheti a megbízható információátvitelt egyrészt az antenna nyereségének irányfüggése (illetve a helyés irányváltozásokkal összefüggően annak folyamatos változása), valamint a fellépő dopplerjelenség miatt.

E terület tehát láthatóan tartalmaz még kiaknázatlan lehetőségeket, így az ilyen irányú kutatások folytatása napjainkban is indokolt. A felmerülő nehézségek ellenére évek óta zajlanak már a témában Magyarországon is UAV-k kommunikációs csatornájának MIMOtechnológiával történő kialakítása érdekében gyakorlati fejlesztések, amelyek komoly eredménnyel kecsegtetnek [41].

\section{Következtetések}

Kutatásom során áttekintettem a távközlés rövid történetét, különös figyelmet fordítva a MIMO történeti hátterének ismertetésére. Bemutattam a technológia müködési alapelveit olyan fogalmakra kitérve, mint a térbeli diverziti, ortogonális frekvenciaosztásos és térbeli multiplexelés, nyalábformálás. Rendszereztem a MIMO-antennarendszerek műszaki megoldásait az adó és vevő oldalon lévő antennák száma szerint. Ezzel kapcsolatosan egyszerü számításokat is végeztem, hogy rávilágítsak a MIMO-megoldások által biztosított előnyök mértékére. Az egyszerü átláthatóság érdekében pontokba szedtem a több bemenettel és több kimenettel rendelkező rádiókommunikációs technológia használatának előnyeit és hátrányait, majd kitértem annak polgári és katonai alkalmazási lehetőségeire. Polgári alkalmazásnál kettő területre fókuszáltam, az 5G-rendszerekre és a müholdas rendszerekre. Katonai alkalmazásnál szintén két területre koncentráltam, a radarrendszerekre és a pilóta nélküli légi járművekre. Általánosan megvizsgáltam az úgynevezett MIMO-radarok koncepcióját, majd a mono-statikus és bi-statikus MIMO-radarokkal is foglalkoztam. Röviden jellemeztem a pilóta nélküli légi járművek katonai feladatrendszerét, aztán ezekre alapozva megállapítottam a MIMO-technológia létjogosultságát e területen. Felvázoltam, hogy ez milyen problémákba ütközhet a gyakorlati megvalósítások esetén, és arra a következtetésre jutottam, hogy további kutatások szükségesek a MIMO-technológia pilóta nélküli légijármü-rendszerekbe történő hatékony integrálása feltételeinek megteremtése érdekében. Összegzésként kijelenthető, hogy a MIMO-technológia a jövőben az emberek mindennapi életében is meghatározó szerepet játszó kommunikációs rendszerek fejlesztésének egyik meghatározó eleme lesz. Szintén nagy változásokat hozhat a katonai alkalmazások területén is, ami akár közvetetten hatással lehet majd a katonai műveletek egyes elemeire. Úgy vélem, hogy az ilyen típusú antennamegoldásokat a távközlés legtöbb területén fel lehet használni valamilyen formában, így a terület kutatása a Magyar Honvédség berkein belül is indokolt lehet a katonai rádiófrekvenciás rendszerek modernizálása során. Polgári részről javaslom 
a Nemzeti Információs Infrastruktúra Fejlesztési (NIIF) Program keretében a MIMO-antennák alkalmazását azokon a területeken, ahol a jövőben nagy adatforgalmak kezelésével lehet számolni. Katonai szempontból pedig javaslom a honvédelmi és haderőfejlesztési program célkitüzéseihez kapcsolódóan a MIMO-antennák alkalmazási lehetőségeinek vizsgálatát a stratégiailag fontos területeken zajló fejlesztésekkel összhangban.

\section{Hivatkozások}

[1] Zs. Bödők, Magyar feltalálók a távközlés történetében. Dunaszerdahely: NAP Kiadó, 2005. [Online]. Elérhető: http://mek.oszk.hu/04500/04500/04500.pdf (Letöltve: 2019. 10. 03.)

[2] Zs. Haig, Információs müveletek a kibertérben. Budapest: Dialóg Campus Kiadó, 2018, pp. 17-76. [Online]. Elérhető: https://akfi-dl.uni-nke.hu/pdf_kiadvanyok/ web_PDF_Informacios_muveletek_a_kiberterben.pdf (Letöltve: 2019. 10. 11.)

[3] A. U. Gawas, „An Overview on Evolution of Mobile Wireless Communication Networks: 1G-6G," International Journal on Recent and Innovation Trends in Computing and Communication, Vol. 3, No. 5, pp. 3130-3133, 2015.

[4] J. T. J. Penttinen, The Telecommunications Handbook: Engineering Guidelines for Fixed, Mobile and Satellite Systems. John Wiley \& Sons Ltd, 2015. DOI: https://doi. org/10.1002/9781118678916

[5] W. van Etten, „Maximum Likelihood Receiver for Multiple Channel Transmission Systems," IEEE Transactions on Communications, Vol. 24, No. 2, pp. 276-283, 1976. DOI: https://doi.org/10.1109/TCOM.1976.1093265

[6] B. Ottersten és R. H. Roy III, "Spatial division multiple access wireless communication systems," Amerikai Egyesült Államok, Szabadalom száma: 5515378, 1996. 05. 07.

[7] A. Paulraj és T. Kailath, „Increasing capacity in wireless broadcast systems using distributed transmission/directional reception (DTDR)," Amerikai Egyesült Államok, Szabadalom száma: 5345599, 1994. 09. 06.

[8] V. K. Jones és G. G. Raleigh, „Channel estimation for wireless OFDM systems," In Proc. IEEE GLOBECOM 1998 (Cat. NO. 98CH36250), Sydney, New South Wales, Australia, 1998. DOI: https://doi.org/10.1109/GLOCOM.1998.776875

[9] T. Koi, „Elfogadták a végleges 802.11n Wi-Fi szabványt," hwsw.hu, 2009. szeptember 14. [Online]. Elérhető: https://www.hwsw.hu/hirek/42931/ieee-wifi-wlan-wifi-wireless-radio-network-szabvany-802-11n-draft-n-wireless-n.html (Letöltve: 2019. 10. 23.)

[10] „WiMAX and the IEEE 802.16m Air Interface Standard - April 2010," WiMAX Forum, 2010. április. [Online]. Elérhető: https://web.archive.org/web/20131207054411/ http://www.wimaxforum.org/sites/wimaxforum.org/files/document_library/wimax _802.16m.pdf (Letöltve: 2019. 10. 23.)

[11] M. Nohrborg, „LTE,” 3gpp.org, 2013. október 29. [Online]. Elérhető: https://www.3gpp. org/technologies/keywords-acronyms/98-lte (Letöltve: 2019. 10. 23.)

[12] „What is MIMO Wireless Technology," electronics-notes.com, [Online]. Elérhető: https://www.electronics-notes.com/articles/antennas-propagation/mimo/what- 
is-mimo-multiple-input-multiple-output-wireless-technology.php (Letöltve: 2019. 11. 09.)

[13] Schindler, Schulz, Introduction to MIMO, Rohde \& Schwarz, Application Note 1MA142, cs.odu.edu, 2009. [Online]. Elérhetö: https://www.cs.odu.edu/ nadeem/classes/ cs752-S16/papers/mimo-005.pdf (Letöltve: 2019. 11. 19.)

[14] Á. Dárdai, „Ortogonális frekvenciaosztású többszörös hozzáférés," Híradástechnika, 59. évf. 4. sz., pp. 22-28., 2004.

[15] I. Mészáros, Triple Play szolgáltatás megvalósitás lehetöségei vezeték nélküli müsor szétosztás mellett. Szakdolgozat, Elérhető: http://vip.tilb.sze.hu/ wersenyi/MI.pdf [Letöltve: 2019. november 20.]

[16] J. M. Kim, S. H. Sohn, N. Han, S. Choi, C. Ahn, G. Hong and Y. Yun, „Chapter 16 Cognitive Radio in Multiple-Antenna Systems," in Cognitive Radio Technology (Second Edition), B. Fette Ed., Academic Press, 2009, pp. 535-556, DOI: https:// doi.org/10.1016/B978-0-12-374535-4.00016-3

[17] A. Németh és V. Folkmann, „Direction Finding Based on Adaptive Antennas,” in Proc. of Radioelektronika 2002, 12th International Czech-Slovak Scientific Conference, Pozsony, Müszaki Egyetem, Szlovákia, 2002.

[18] A. Németh és V. Folkmann, „Iránymérés adaptív antennarendszerrel," Híradástechnika, 59. évf. 3. sz., pp. 49-54., 2004.

[19] A. Krumbein, Understanding the Basics of MIMO Communication Technology. Southwest Antennas, 2016. [Online]. Elérhető: https://www.rfmw.com/data/swa-mimobasics.pdf (Letöltve: 2019. 11. 09.)

[20] C. Hamby, „What is MIMO Technology?,” 2013. december 4. [Online]. Elérhető: https://www.avalan.com/blog/bid/356942/What-is-MIMO-Technology (Letöltve: 2019. 11. 15.)

[21] B. Schulz, LTE Transmission Modes and Beamforming. Rohde \& Schwarz, White Paper 1MA186_2e, 2015. [Online]. Elérhető: https://scdn.rohde-schwarz.com/ur/pws/ dl_downloads/dl_application/application_notes/1ma186/1MA186_2e_LTE_TMs_ and_beamforming.pdf (Letöltve: 2019. 11. 19.)

[22] E. Geier, "MU-MIMO vs SU-MIMO Wi-Fi," techgenix.com, 2015. [Online]. Elérhető: http://techgenix.com/mu-mimo-vs-su-mimo-wi-fi/ (Letöltve: 2019. 11. 19.)

[23] E. Luther, „5G Masszív MIMO tesztkörnyezet," elektro-net.hu, 2015. [Online]. Elérhető: https://elektro-net.hu/rendszerintegrator/6865-5g-massziv-mimo-tesztkornyezet (Letöltve: 2020. 01. 11.)

[24] T. L. Marzetta, „Massive MIMO: An Introduction,” Bell Labs Technical Journal, Vol. 20, pp. 11-22, 2015. DOI: https://doi.org/10.15325/BLTJ.2015.2407793

[25] D. A. Hall, „Understanding Benefits Of MIMO Technology," mwrf.com, 2009. [Online]. Elérhetö: https://www.mwrf.com/markets/article/21846554/understanding-benefits-of-mimo-technology\#close-olyticsmodal (Letöltve: 2019. 11. 09.)

[26] A. Nordrum és K. Clark, „Everything You Need to Know About 5G," spectrum.ieee. org, 2017. [Online]. Elérhetö: https://spectrum.ieee.org/video/telecom/wireless/ everything-you-need-to-know-about-5g (Letöltve: 2020. 01. 13.)

[27] C-X. Wang, F. Haider, X. Gao, X-H. You, Y. Yang, D. Yuan, H. M. Aggoune, H. Haas, S. Fletcher and E. Hepsaydir, "Cellular Architecture and Key Technologies for $5 \mathrm{G}$ 
Wireless Communication Networks," IEEE Communications Magazine, Vol. 52, No. 2, pp. 122-130, 2014. DOI: https://doi.org/10.1109/mcom.2014.6736752

[28] A. Németh, „Adaptív antennarendszer hardverének realizációja,” Bolyai Szemle, 13. évf. 1. sz., pp. 75-83, 2004.

[29] J. Rodriguez, Fundamentals of $5 G$ Mobile Networks. John Wiley \& Sons, Inc. , 2015. DOI: https://doi.org/10.1002/9781118867464

[30] A. Németh, E. Hegedűs, A. Wippelhauser és R. Simó, „A katonai alkalmazású terepi autonóm járművek fejlesztésének egyes kérdései l. rész," Haditechnika, 53. évf. 4. sz., PP. 11-16., 2019. DOI: https://doi.org/10.23713/HT.53.4.02

[31] B. Ramamurthy, „MIMO for Satellite Communication," Ph.D Thesis, University of South Australia,Institute for Telecommunications Research, 2018.

[32] D. J. Rabideau and P. A. Parker, „Ubiquitous MIMO multifunction digital array radar," In Proc. of The Thrity-Seventh Asilomar Conference on Signals, Systems \& Computers, Pacific Grove, CA, USA, 2003. DOI: https://doi.org/10.1109/acssc.2003.1292087

[33] J. Li and P. Stoica, MIMO Radar Signal Processing. John Wiley \& Sons, Inc. , 2008. DOI: https://doi.org/10.1002/9780470391488

[34] A.R. Nur Emileen, S. Asem, A. Noor Hafizah, O. Kama Azura, M.Y. H. Hazwan and R. A. Syamsul Azmir, "RCS analysis on different targets and bistatic angles using LTE frequency," In Proc. of 16th International Radar Symposium (IRS), 2015. DOI: https://doi.org/10.1109/irs.2015.7226397

[35] A. Németh, „Technical Dimensions of the Development of Unmanned Aerial Systems and Their Impact on Public Service Uses," AARMS, Vol. 17, No. 3, pp. 149-163, 2018.

[36] A. Németh, „UAV-k alkalmazása a közfeladatok ellátása során I., " Hadmérnök, 13. évf. 2. sz., pp. 37-60., 2018. [Online]. Elérhető: http://hadmernok.hu/182_04_nemeth. pdf (Letöltve: 2020. 11. 19.)

[37] S. K. Jindal, „MIMO Systems for Military Communication/Applications," International Journal of Engineering Research and Applications, Vol. 6, No. 4, pp. 22-33, 2016.

[38] A. Németh, „UAV-k alkalmazása a közfeladatok ellátása során II., " Hadmérnök, 13. évf. 3. sz., pp. 68-86., 2018. [Online]. Elérhető: http://real.mtak.hu/87038/1/183_06_ nemeth.pdf (Letöltve: 2020. 11. 19.)

[39] A. Bolea Alamanac, P-D. M. Arapoglou, P. Burzigotti and R. De Gaudenzi, „Capacity potential of mobile satellite broadcasting systems employing dual polarization per beam," In Proc. of 5th Advanced Satellite Multimedia Systems Conference and the 11th Signal Processing for Space Communications Workshop, Cagliari, 2010. DOI: https://doi.org/10.1109/asms-spsc.2010.5586911

[40] E. Bonek, N. Czink and H. Ozcelik, „What makes a good MIMO channel model?," In Proc. of IEEE 61st Vehicular Technology Conference, Stockholm, 2005. DOI: https:// doi.org/10.1109/vetecs.2005.1543269

[41] Gy. Mikó és A. Németh, „SCFDM based communication system for UAV applications," In Proc. of 25th International Conference Radioelektronika, Pardubice, Czech Republic, 21-22 April 2015, pp. 222-224. DOI: https://doi.org/10.1109/RADIOELEK.2015.7129014 